\title{
Longevity and survival curves of Rhinella icterica (Anura, Bufonidae) under laboratory conditions
}

\author{
Lima, MSCS. ${ }^{a *}$, Pederassi, J., ${ }^{b, c}$ and Souza, CAS. ${ }^{d}$ \\ ${ }^{a}$ Universidade Federal do Piauí - UFPI, Campus Amilcar Ferreira Sobral, BR 343, \\ Km 3,5, CEP 64800-000, Floriano, PI, Brazil \\ 'ONG Bioma, Rua Queluz, 125, São Cristóvão, CEP 27264-820, Volta Redonda, RJ, Brazil \\ ${ }^{\mathrm{c}}$ Museu Nacional, Departamento de Vertebrados, Universidade Federal do Rio de Janeiro - UFRJ, Quinta da Boa Vista, \\ São Cristóvão, CEP 20940-040, Rio de Janeiro, RJ, Brazil

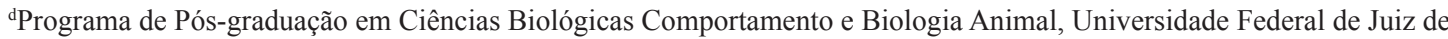 \\ Fora - UFJF, Campus Universitário Martelos, Martelos, CEP 36036-330, Juiz de Fora, MG, Brazil \\ *e-mail: slmauro@ufpi.edu.br
}

Received January 23, 2013 - Accepted March 1, 2013 - Distributed May 31, 2014

(With 4 figures)

\begin{abstract}
Life tables and survival curves of tadpoles from Rhinella icterica species were studied in the laboratory, under abiotic conditions controlled by a purification filter, a timer and a chiller. The survival curve for larval stage confirms a great mortality trend in the initial stages, which decreases when reaching the mature morphological condition $(\mathrm{r}=-0.94)$. Stages 37, 38, 39, 40 and 41 showed gradual values for their age structures, while stages 42,43 and 44 presented high variations. Based on the results under laboratory conditions, it can be concluded that the maturity of $R$. icterica tadpoles development between 37 and 44 stages has a negative correlation and their predicted life expectancy is a logarithmic growth curve $(\mathrm{y}=-761.96 \operatorname{Ln}(\mathrm{x})+5298.5)$.
\end{abstract}

Keywords: tadpole, life table, reproduction.

\section{Longevidade e curva de sobrevivência de Rhinella icterica (Anura, Bufonidae) em condições de laboratório}

\begin{abstract}
Resumo
Tabelas de vida e curvas de sobrevivência em estágios larvais de girinos da espécie Rhinella icterica foram estudadas em laboratório, sob condições abióticas controladas com uso de filtro de depuração, timer e chiller. A curva de sobrevivência por estágio larval confirma a tendência de maior mortalidade para os estágios iniciais e menor mortalidade para o avanço da condição morfológica madura $(\mathrm{r}=-0,94)$. Os estágios $37,38,39,40$ e 41 apresentaram valores gradativos para sua estrutura etária, enquanto nos estágios 42,43 e 44 ocorreram variações acentuadas. Com base nos resultados obtidos, nas condições de laboratório, pode-se concluir que a maturidade de desenvolvimento de girinos de $R$. icterica entre os estágios 37 e 44, apresenta correlação negativa e a predição de esperança de vida a uma curva logarítmica de crescimento $(\mathrm{y}=761,96 \operatorname{Ln}(\mathrm{x})+5298,5)$.
\end{abstract}

Palavras-chave: girino, tabela de vida, reprodução.

\section{Introduction}

Most anuran species have a complex life cycle: aquatic tadpoles metamorphose into terrestrial adults, becoming typically different in overall morphology, physiology and behaviour (Duellman and Trueb, 1994). Environmental shifts potentially affect species, especially in life cycle stages most susceptible to ambient changing conditions. In this sense, the use of larval characters is very common among herpetologists - both for the diagnosis of species and for determination of intra-and intergeneric systematic relationships (Carneiro et al., 2004; Nascimento and Skuk, 2006; Casal and Juncá, 2008; Vieira and Arzabe, 2008).
The study of developmental change among anurans resulted in a staging table created by Gosner (1960), with the description of anuran embryos and larva through 46 developmental stages. However, the survival curves of tadpoles as well as their longevity still require deeper research.

Studies of structured populations (life expectancy tables) were initiated by Pearl et al. (1927), representing the life expectancy of a population by a numerical expression, which measured mortality and longevity of animal species submitted to certain conditions. 
The most widely used tool applied in population modelling consists of a discrete age and stage-structured model, tracking dynamical aspects of a species (Freckleton et al., 2003; Gotelli, 2007).

The Bufonidae family is composed of 34 genera with a worldwide distribution, except for Antarctica and Australia (Zug et al., 2001; AmphibiaWeb, 2013). With the revision of Frost et al. (2006) the so-called Bufo genus was renamed Chaunus, but a new revision (Chaparro et al., 2007) rearranged this group and incorporated Chaunus and Rhamphophryne in Rhinella genus, which now has 86 species (Frost, 2013), being R. icterica from the group of $R$. marina (Linnaeus, 1758), comprising 10 species (Tolledo and Toledo, 2010; Frost, 2013) and Bufo remainig a valid genus in Eurasia (Chaparro et al., 2007; Frost, 2013).

Rhinella icterica (Spix, 1823) has a wide occurrence in southeast Brazil, in a large diversity of habitats (Amphibiaweb, 2013). According to Silvano et al. (2010) there are no known threats to this species that even adapts to human-altered habitats.

The goal of the present study was to build both a structured growth model and a larval stage-longevity curve for the toad Rhinella icterica, a species that is clearly tolerant to man-altered environments.

\section{Material and Methods}

Tadpoles were collected in the Cachimbaú River, in the Pinheiral municipality, State of Rio de Janeiro, Brazil. Voucher specimens are deposited in the collection Eugenio Izecksohn (EI 11 012). Whenever the school of tadpoles was found, sieves were used to collect them $(400 \times 700$ $\mathrm{mm}$ mesh of $0.05 \times 0.05 \mathrm{~mm})$ until getting to the ideal initial experimental sample $-1,000$ individuals in stage 37 (Lima and Peixoto, 2007). The number of individuals in subsequent stages corresponded to those tadpoles that survived and metamorphosed. When specimens were collected, dissolved oxygen (DO) was measured in loco with Quimis Q408 oximeter (precision $0.3 \mathrm{mg} / \mathrm{l}$ ), $\mathrm{pH}$ was measured using a Hanna $\mathrm{pHmeter}$ and nitrite concentration with Alfakit 1307. Measurements were taken for five consecutive days and 4-hour intervals, from 6:00 AM to 12:00 PM.

\subsection{Aqua-terrarium}

An aqua-terrarium with chiller has been used for this study, in order to obtain an optimised control of abiotic conditions - providing similar variations to those of the environment under analysis. The aqua-terrarium measured $107 \times 35 \times 52 \mathrm{~cm}$ with an external filter system of $37 \times$ $34 \times 48 \mathrm{~cm}$. Chiller compressor with $1.8 \mathrm{hp}$ and timer for setting up the frequency of pump flow. Feed pump of 1200 $1 / \mathrm{h}$, return pump of $250 \mathrm{l} / \mathrm{h}$ and aeration pump $500 \mathrm{l} / \mathrm{h}$.

\subsection{Environmental control of the Aqua-terrarium}

On a daily basis, dissolved oxygen was measured with a Q-408 QUIMIS oxygen meter (accuracy $\pm 0.3 \mathrm{mg} / \mathrm{l}$ ), $\mathrm{pH}$ was measured with a HANNA pHmeter and nitrite concentration was measured with an ALFAKIT 1307.
Temperature was measured using a submerged thermometer. The maintained these variables by the aeration pump and debugging tank with two biological filters, automatically debugging every 6 hours. The chiller was programmed to activate automatically in order to maintain the water temperature ranging between 23 and $25^{\circ} \mathrm{C}$.

\subsection{Mathematical model}

For a better estimate of lifetimes, daily records were taken of the number of individuals per stage, among survivors, metamorphosed and dead. In the construction of life tables according to Silveira Neto et al. (1976) - adapted to the study of anuran larval development - the parameters below were arranged in columns according to the larval stage in unit time (x days). Lx is the fraction of survivors, on each " $\mathrm{x}$ " interval; $\mathrm{dx}$ is the fraction of individuals that metamorphosed or died between the ages " $x$ " and " $x+1$ " - this was estimated through the formula $\mathrm{Lx}-(\mathrm{Lx}+1)$. The value of Ex (average survival probability among larval stages on successive metamorphosis) was calculated by formula $\mathrm{Lx}-(1 / 2(\mathrm{dx}))$, representing the age structure. Tx was estimated by the formula $\Sigma \mathrm{Ex}+(\mathrm{Ex}+1)+\mathrm{Ew}$, where "w" is the maximum larval stage in weeks; life expectancy will be estimated by Tx/Lx. Mortality ratio (qx) by age interval was estimated by $1000 \mathrm{qx}(\mathrm{dx} / \mathrm{Lx})$; data longevity of each stage was analyzed using the Pearson correlation coefficient and $t$ variance test, for n- 1 degrees of freedom (DF) and $\alpha=0.05$.

The biotic potential was represented by a graph where individuals on stage 37 should reach stage 44 . The biotic perpetuation was also represented by a graph, which measured how many individuals on stage 37 (in the beginning of the experiment) reached stage 44 . The equations of both graphs were calculated and the differences were expressed on a mathematical model that predicts the life expectancy by larval stage.

\section{Results and Discussion}

Tables 1 to 8 show the parameters of life expectancy by larval stage. In the analysis of life table, the concept of survival is essential, thus the terms Ex, Tx and Lx express the age structure of population in a given time interval. Stages 37, 38, 39, 40 and 41 showed gradual values (five to eight days) for their age structures. However, stages 42 , 43 and 44 presented high variations of eleven, fourteen and seventeen days.

The estimated life expectancy (Ex), considering "day" a time measurement unit $(\mathrm{x})$ is represented in Tables 1 to 8 below:

Rhinella icterica age monitoring and its biological cycle were described by Rosa (1951). That study did not set the range of days between the last larval stage and the young stage (imago); also, the stages proposed by Gosner (1960) were not known. However, we found similarities relating to the metamorphosis cycle proposed by Rosa (1951) and ours, that is, the older stages takes longer to reach the next stage. As for the differences between Rosa (1951) results 
Table 1. Life expectancy for stage 37 of Rhinella icterica under controlled laboratory conditions. $\mathrm{x}=$ age interval in days; $\mathrm{Lx}=$ fraction of survivors on each " $\mathrm{x}$ " interval; $\mathrm{dx}$ : the fraction of individuals that metamorphosed or died between the ages " $\mathrm{x}$ " and " $\mathrm{x}+1$ "; $\mathrm{Ex}=$ age structure; $\mathrm{Tx}=$ total number of tadpoles of " $\mathrm{x}$ " age beyond the " $\mathrm{x}$ " age; ex: life expectancy; $\mathrm{qX}=$ risk ratio by age.

\begin{tabular}{ccccccc}
\hline $\mathbf{x}$ & $\mathbf{L x}$ & $\mathbf{d x}$ & $\mathbf{E x}$ & $\mathbf{T x}$ & $\mathbf{e x}$ & $\mathbf{1 0 0 0 q X}$ \\
\hline 1 & 1000 & 0 & 1000 & 3193 & 3.193 & 0 \\
2 & 1000 & 176 & 912 & 2193 & 2.193 & 176 \\
3 & 824 & 256 & 696 & 1281 & 1.554612 & 310.6796 \\
4 & 568 & 267 & 434.5 & 585 & 1.02993 & 470.0704 \\
5 & 301 & 301 & 150.5 & 150.5 & 0.5 & 1000 \\
\hline
\end{tabular}

Table 2. Life expectancy for stage 38 of Rhinella icterica under controlled laboratory conditions. $\mathrm{x}=$ age interval in days; $\mathrm{Lx}=$ fraction of survivors on each " $\mathrm{x}$ " interval; $\mathrm{dx}$ : the fraction of individuals that metamorphosed or died between the ages " $\mathrm{x}$ " and " $\mathrm{x}+1$ "; $\mathrm{Ex}=$ age structure; $\mathrm{T} x=$ total number of tadpoles of " $\mathrm{x}$ " age beyond the " $\mathrm{x}$ " age; ex: life expectancy; $\mathrm{qX}=$ risk ratio by age.

\begin{tabular}{ccccccc}
\hline $\mathbf{x}$ & $\mathbf{L x}$ & $\mathbf{d x}$ & $\mathbf{E x}$ & $\mathbf{T x}$ & $\mathbf{e x}$ & $\mathbf{1 0 0 0 q X}$ \\
\hline 1 & 870 & 0 & 870 & 2736 & 3.144828 & 0 \\
2 & 870 & 176 & 782 & 1866 & 2.144828 & 176 \\
3 & 694 & 227 & 580.5 & 1084 & 1.56196 & 284.5677 \\
4 & 467 & 267 & 333.5 & 503.5 & 1.078158 & 497.409 \\
5 & 200 & 130 & 135 & 170 & 0.85 & 565.5 \\
6 & 70 & 70 & 35 & 35 & 0.5 & 870 \\
\hline
\end{tabular}

Table 3. Life expectancy for stage 39 of Rhinella icterica under controlled laboratory conditions. $\mathrm{x}=$ age interval in days; $\mathrm{Lx}=$ fraction of survivors on each " $\mathrm{x}$ " interval; $\mathrm{dx}$ : the fraction of individuals that metamorphosed or died between the ages " $\mathrm{x}$ " and " $\mathrm{x}+1$ "; Ex= age structure; $\mathrm{T} x=$ total number of tadpoles of " $\mathrm{x}$ " age beyond the " $\mathrm{x}$ " age; ex: life expectancy; $\mathrm{qX}=$ risk ratio by age.

\begin{tabular}{ccccccc}
\hline $\mathbf{x}$ & $\mathbf{L x}$ & $\mathbf{d x}$ & $\mathbf{E x}$ & $\mathbf{T x}$ & $\mathbf{e x}$ & $\mathbf{1 0 0 0 q X}$ \\
\hline 1 & 780 & 15 & 772.5 & 3193 & 4.09359 & 15 \\
2 & 765 & 68 & 731 & 2420.5 & 3.164052 & 69.33333 \\
3 & 697 & 120 & 637 & 1689.5 & 2.42396 & 134.2898 \\
4 & 577 & 180 & 487 & 1052.5 & 1.82409 & 243.3276 \\
5 & 397 & 118 & 338 & 565.5 & 1.424433 & 231.8388 \\
6 & 279 & 191 & 183.5 & 227.5 & 0.815412 & 533.9785 \\
7 & 88 & 88 & 44 & 44 & 0.5 & 780 \\
\hline
\end{tabular}

Table 4. Life expectancy for stage 40 of Rhinella icterica under controlled laboratory conditions. $\mathrm{x}=$ age interval in days; $\mathrm{Lx}=$ fraction of survivors on each " $\mathrm{x}$ " interval; $\mathrm{dx}$ : the fraction of individuals that metamorphosed or died between the ages " $\mathrm{x}$ " and " $\mathrm{x}+1$ "; Ex= age structure; Tx= total number of tadpoles of " $\mathrm{x}$ " age beyond the " $\mathrm{x}$ " age; ex: life expectancy; $\mathrm{qX}=$ risk ratio by age.

\begin{tabular}{ccccccc}
\hline $\mathbf{x}$ & $\mathbf{L x}$ & $\mathbf{d x}$ & $\mathbf{E x}$ & $\mathbf{T x}$ & $\mathbf{e x}$ & $\mathbf{1 0 0 0 q X}$ \\
\hline 1 & 710 & 0 & 710 & 2718 & 3.828169 & 0 \\
2 & 710 & 118 & 651 & 2008 & 2.828169 & 118 \\
3 & 592 & 135 & 524.5 & 1357 & 2.29223 & 161.9088 \\
4 & 457 & 162 & 376 & 832.5 & 1.821663 & 251.6849 \\
5 & 295 & 88 & 251 & 456.5 & 1.547458 & 211.7966 \\
6 & 207 & 120 & 147 & 205.5 & 0.992754 & 411.5942 \\
7 & 87 & 72 & 51 & 58.5 & 0.672414 & 587.5862 \\
8 & 15 & 15 & 7.5 & 7.5 & 0.5 & 710 \\
\hline
\end{tabular}


Table 5. Life expectancy for stage 41 of Rhinella icterica under controlled laboratory conditions. $\mathrm{x}=$ age interval in days; $\mathrm{Lx}=$ fraction of survivors on each " $\mathrm{x}$ " interval; $\mathrm{dx}$ : the fraction of individuals that metamorphosed or died between the ages " $\mathrm{x}$ " and " $\mathrm{x}+1$ "; $\mathrm{Ex}=$ age structure; $\mathrm{Tx}=$ total number of tadpoles of " $\mathrm{x}$ " age beyond the " $\mathrm{x}$ " age; ex: life expectancy; $\mathrm{qX}=$ risk ratio by age.

\begin{tabular}{ccccccc}
\hline $\mathbf{x}$ & $\mathbf{L x}$ & $\mathbf{d x}$ & $\mathbf{E x}$ & $\mathbf{T x}$ & $\mathbf{e x}$ & $\mathbf{1 0 0 0 q X}$ \\
\hline 1 & 630 & 0 & 630 & 2249 & 3.569841 & 0 \\
2 & 630 & 22 & 619 & 1619 & 2.569841 & 22 \\
3 & 608 & 133 & 541.5 & 1000 & 1.644737 & 137.8125 \\
4 & 475 & 367 & 291.5 & 458.5 & 0.965263 & 486.7579 \\
5 & 108 & 44 & 86 & 167 & 1.546296 & 256.6667 \\
6 & 64 & 15 & 56.5 & 81 & 1.265625 & 147.6563 \\
7 & 49 & 49 & 24.5 & 24.5 & 0.5 & 630 \\
\hline
\end{tabular}

Table 6. Life expectancy for stage 42 of Rhinella icterica under controlled laboratory conditions. $\mathrm{x}=$ age interval in days; $\mathrm{Lx}=$ fraction of survivors on each " $\mathrm{x}$ " interval; $\mathrm{dx}$ : the fraction of individuals that metamorphosed or died between the ages " $\mathrm{x}$ " and " $\mathrm{x}+1$ "; $\mathrm{Ex}=$ age structure; $\mathrm{T} x=$ total number of tadpoles of " $\mathrm{x}$ " age beyond the " $\mathrm{x}$ " age; ex: life expectancy; $\mathrm{qX}=$ risk ratio by age.

\begin{tabular}{ccccccc}
\hline $\mathbf{x}$ & $\mathbf{L x}$ & $\mathbf{d x}$ & $\mathbf{E x}$ & $\mathbf{T x}$ & $\mathbf{e x}$ & $\mathbf{1 0 0 0 q} \mathbf{X}$ \\
\hline 1 & 555 & 29 & 540.5 & 3544.5 & 6.386486 & 29 \\
2 & 526 & 7 & 522.5 & 3004 & 5.711027 & 7.385932 \\
3 & 519 & 10 & 514 & 2481.5 & 4.78131 & 10.69364 \\
4 & 509 & 38 & 490 & 1967.5 & 3.865422 & 41.43418 \\
5 & 471 & 74 & 434 & 1477.5 & 3.136943 & 87.19745 \\
6 & 397 & 96 & 349 & 1043.5 & 2.628463 & 134.2065 \\
7 & 301 & 65 & 268.5 & 694.5 & 2.307309 & 119.8505 \\
8 & 236 & 51 & 210.5 & 426 & 1.805085 & 119.9364 \\
9 & 185 & 108 & 131 & 215.5 & 1.164865 & 324 \\
10 & 77 & 31 & 61.5 & 84.5 & 1.097403 & 223.4416 \\
11 & 46 & 46 & 23 & 23 & 0,5 & 555 \\
\hline
\end{tabular}

Table 7. Life expectancy for stage 43 of Rhinella icterica under controlled laboratory conditions. $\mathrm{x}=$ age interval in days; $\mathrm{Lx}=$ fraction of survivors on each " $\mathrm{x}$ " interval; $\mathrm{dx}$ : the fraction of individuals that metamorphosed or died between the ages " $\mathrm{x}$ " and " $\mathrm{x}+1$ "; Ex= age structure; Tx= total number of tadpoles of " $\mathrm{x}$ " age beyond the " $\mathrm{x}$ " age; ex: life expectancy; $\mathrm{qX}=$ risk ratio by age.

\begin{tabular}{ccccccc}
\hline $\mathbf{x}$ & $\mathbf{L x}$ & $\mathbf{d x}$ & $\mathbf{E x}$ & $\mathbf{T x}$ & $\mathbf{e x}$ & $\mathbf{1 0 0 0 q} \mathbf{X}$ \\
\hline 1 & 480 & 53 & 453.5 & 2573 & 5.360417 & 53 \\
2 & 427 & 79 & 387.5 & 2119.5 & 4.9637 & 88.80562 \\
3 & 348 & 53 & 321.5 & 1732 & 4.977011 & 73.10345 \\
4 & 295 & 18 & 286 & 1410.5 & 4.781356 & 29.28814 \\
5 & 277 & 31 & 261.5 & 1124.5 & 4.059567 & 53.71841 \\
6 & 246 & 32 & 230 & 863 & 3.50813 & 62.43902 \\
7 & 214 & 53 & 187.5 & 633 & 2.957944 & 118.8785 \\
8 & 161 & 32 & 145 & 445.5 & 2.767081 & 95.40373 \\
9 & 129 & 26 & 116 & 300.5 & 2.329457 & 96.74419 \\
10 & 103 & 48 & 79 & 184.5 & 1.791262 & 223.6893 \\
11 & 55 & 16 & 47 & 105.5 & 1.918182 & 139.6364 \\
12 & 39 & 13 & 32.5 & 58.5 & 1,5 & 160 \\
13 & 26 & 13 & 19.5 & 26 & 1 & 240 \\
14 & 13 & 13 & 6.5 & 6.5 & 0.5 & 480 \\
\hline
\end{tabular}


Table 8. Life expectancy for stage 44 of Rhinella icterica under controlled laboratory conditions. $\mathrm{x}=$ age interval in days; $\mathrm{Lx}=$ fraction of survivors on each " $\mathrm{x}$ " interval; $\mathrm{dx}$ : the fraction of individuals that metamorphosed or died between the ages " $\mathrm{x}$ " and " $\mathrm{x}+1$ "; $E x=$ age structure; $T \mathrm{x}=$ total number of tadpoles of " $\mathrm{x}$ " age beyond the " $\mathrm{x}$ " age; ex: life expectancy; $\mathrm{qX}=$ risk ratio by age.

\begin{tabular}{ccccccc}
\hline $\mathbf{x}$ & $\mathbf{L x}$ & $\mathbf{d x}$ & $\mathbf{E x}$ & $\mathbf{T x}$ & $\mathbf{e x}$ & $\mathbf{1 0 0 0 q} \mathbf{X}$ \\
\hline 1 & 450 & 35 & 432.5 & 3522 & 7.826667 & 35 \\
2 & 415 & 35 & 397.5 & 3089.5 & 7.444578 & 37.95181 \\
3 & 380 & 48 & 356 & 2692 & 7.084211 & 56.84211 \\
4 & 332 & 21 & 321.5 & 2336 & 7.036145 & 28.46386 \\
5 & 311 & 22 & 300 & 2014.5 & 6.477492 & 31.8328 \\
6 & 289 & 10 & 284 & 1714.5 & 5.932526 & 15.57093 \\
7 & 279 & 19 & 269.5 & 1430.5 & 5.12724 & 30.64516 \\
8 & 260 & 18 & 251 & 1161 & 4.465385 & 31.15385 \\
9 & 242 & 14 & 235 & 910 & 3.760331 & 26.03306 \\
10 & 228 & 37 & 209.5 & 675 & 2.960526 & 73.02632 \\
11 & 191 & 21 & 180.5 & 465.5 & 2.437173 & 49.47644 \\
12 & 170 & 84 & 128 & 285 & 1.676471 & 222.3529 \\
13 & 86 & 19 & 76.5 & 157 & 1.825581 & 99.4186 \\
14 & 67 & 49 & 42.5 & 80.5 & 1.201493 & 329.1045 \\
15 & 18 & 0 & 18 & 38 & 2.111111 & 0 \\
16 & 18 & 7 & 14.5 & 20 & 1.111111 & 175 \\
17 & 11 & 11 & 5.5 & 5.5 & 0.5 & 450 \\
\hline
\end{tabular}

versus our results, when submitting them to the $t$ test, no significant discrepancies were noted (see Figure 1).

The survival curve per larval stage confirms the trend of higher mortality in the early stages and lower mortality as advancing on the mature morphologic condition (see Figure 2). When assessing the statistical dependence between the larval stage and mortality, we evidenced, based on Pearson's correlation coefficient, a negative correlation $(\mathrm{r}=-0.94)$, implying that a greater maturity tends to a lower mortality.

Under laboratory-controlled conditions, nitrite was kept between 0.25 and $0.50 \mathrm{ppm}, \mathrm{pH}$ between 6.8 and 7.4 , dissolved oxygen between 8 and $10.16 \mathrm{mh} / 1$ and temperature between 23 and $25^{\circ} \mathrm{C}$. (see Figure 3). External measurements: $\mathrm{pH} 6.7(\mathrm{SD}=0.7)$, dissolved oxygen 8.3 $\mathrm{mh} / 1(\mathrm{SD}=2.2), 0.21 \mathrm{ppm}$ nitrite $(\mathrm{SD}=0.2)$. Among the measured abiotic factors, nitrite is the only one that presented differences $(0.9 \mathrm{ppm})$ between aqua-terrarium and external conditions. We believe that although the water was in continuous flux through the use of pumps, the aqua-terrarium environment offers little dilution of nitrite, which may raise mortality rates.

Based on the results obtained, on the conditions in which the study was developed, we conclude that even in controlled laboratory conditions mortality occurs and the curve is negatively expressed, that is, the longer the maturity stage, the lower the mortality. When submitting the values for the biotic potential of the population, along with the biotic perpetuation on a life expectancy curve, differences were found for all larval stages ( 37 to 44 ) and this range of numerical differences was called environmental resistance (see Figure 4).

On each larval stage, the differences found between the number of individuals that should morph into the next stage

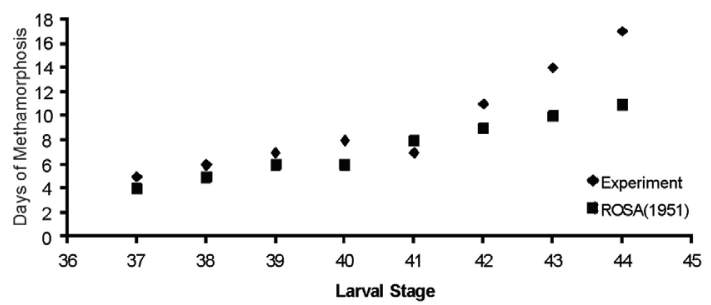

Figure 1. Comparison between the results found by Rosa (1951) and this experiment regarding the developmental stages of Rhinella icterica.

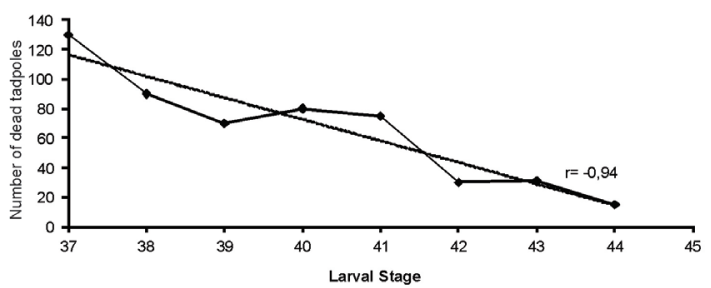

Figure 2. Correlation between larval stage and mortality.

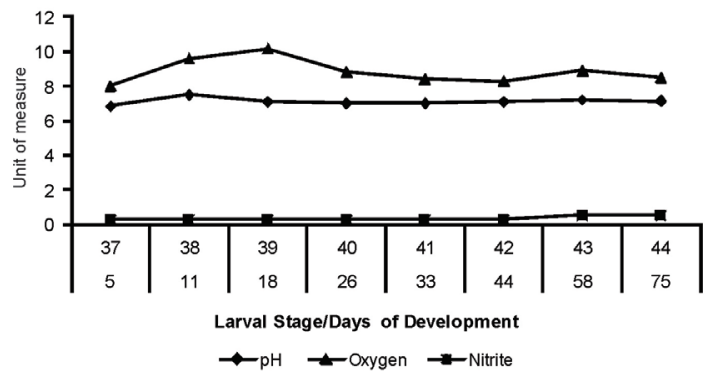

Figure 3. Abiotic variation of aqua-terrarium under controlled laboratory conditions. 


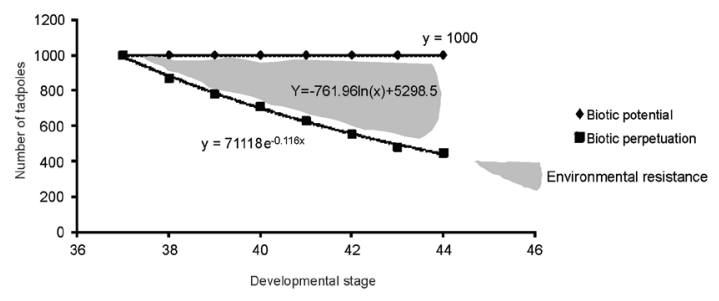

Figure 4. Life expectancy curve.

and the number of individuals that actually metamorphosed correspond to an exponential $\left(\mathrm{y}=71118 \mathrm{e}^{-1155 \mathrm{x}}\right)$ in contrast to the biotic potential which should correspond to $\mathrm{Y}=1000$. The difference between these two curves, expected and achieved, predicts the logarithmic model of life expectancy corresponding to $\mathrm{y}=-761.96 \operatorname{Ln}(\mathrm{x})+5298.5$.

Based on the results obtained in laboratory conditions, it can be concluded that the development maturity of tadpoles of $R$. icterica between stages 37 and 44 is negatively correlated and its life expectancy prediction is a logarithmic growth curve.

Acknowledgements - We would like to thank Professors Flora A. Juncá (UEFS), Reginaldo Assêncio Machado (UFAC) and the anonymous reviewer for their helpful and critical review of the present work.

\section{References}

AmphibiaWeb,2013. Information on amphibian biology and conservation. Berkeley: AmphibiaWeb. Available from: $<\mathrm{http}$ :/ amphibiaweb.org/>. Access in: 24 Jan. 2013.

CARNEIRO, MCL., MAGALHÃES, PS. and JUNCÁ, FA., 2004. Descrição do girino e vocalização de Scinax pachycrus (MirandaRibeiro, 1937) (Amphibia, Anura, Hylidae). Arquivos do Museu Nacional. Museu Nacional (Brazil), vol. 62, no. 3, p. 241-246.

CASAL, FC. and JUNCÁ, FA., 2008. Girino e canto de anúncio de Hypsiboas crepitans (Amphibia: Anura: Hylidae) do estado da Bahia, Brasil, e considerações taxonômicas. Boletim do Museu Paraense Emílio Goeldi, vol. 3, no. 3, p. 217-224.

CHAPARRO, JC., PRAMUK, JB. and GLUESENKAMP, AG., 2007. A new species of arboreal Rhinella (Anura: Bufonidae) from a cloud forest of southeastern Peru. Herpetologica, vol. 63, no. 2, p. 203-212. http://dx.doi.org/10.1655/0018-0831(2007)63[203:AN SOAR]2.0.CO;2.

DUELLMAN, WE. and TRUEB, L.,1994. Biology of amphibians. Baltimore: Johns Hopkins Press.

FRECKLETON, RP., SILVA MATOS, DM., BOVI, M LA. and WATKINSON, AR., 2003. Predicting the impacts of harvesting using structured population models: the importance of densitydependence and timing of harvest for a tropical palm tree. Journal of Applied Ecology, vol. 40, no. 5, p. 846-858. http://dx.doi. org/10.1046/j.1365-2664.2003.00842.x.

FROST, DR.,2013. Amphibian Species of the World. Version 5.6. New York: American Museum of Natural History. Available from: $<$ http://research.amnh.org/vz/herpetology/amphibia/index.php $>$. Access in: 27 Jan. 2013

FROST, DR., GRANT, T., FAIVOVICH, J., BAIN, RH., HAAS, A., HADDAD, CFB., DE SÁ, RO., CHANNING, A., WILKINSON, M., DONNELLAN, SC., RAXWORTHY, CJ., CAMPBELL, JA., BLOTTO, BL., MOLER, P., DREWES, RC., NUSSBAUM, RA., LYNCH, JD., GREEN, DM. and WHEELER, WC.,2006. The amphibian tree of life. New York: American Museum of Natural History. p. 1-370. Bulletin of the American Museum of Natural History, no. 297.

GOSNER, KL., 1960. A simplified table for staging anuran embryos and larva with notes on identification. Herpetologica, vol. 16 , no. 2 , p. 183-190.

GOTELLI, NJ., 2007. Ecologia. 3. ed. Londrina: Planta.

LIMA, MSCS. and PEIXOTO, OL., 2007. Comportamento de girinos de Chaunus ictericus Spix, 1824 (Anura, Bunfonidae) em diferentes concentrações de oxigênio dissolvido. Revista Brasileira de Zoociências, vol. 9, no. 1, p. 103-109.

NASCIMENTO, FA.,C. and SKUK, GO., 2006. O girino de Chiasmocleis alagoanus Cruz, Caramaschi \& Freire, 1999 (Anura, Microhylidae). Biota Neotropica, vol. 6, no. 3. Available from: $<$ http:// www.biotaneotropica.org.br/v6n3/pt/fullpaper?bn02506032006+pt>. Access in: 10 Apr. 2011.

PEARL, R., MINER, JR. and PARKER, SL., 1927. Experimental studies on the duration of life. XI. Density of population and life duration in Drosophila. American Naturalist, vol. 61, p. 289-318. http://dx.doi.org/10.1086/280154.

ROSA, CN., 1951. Notas sobre o desenvolvimento normal de um sapo Bufo ictericus. Boletim da Faculdade de Filosofia, Ciências e Letras, Universidade de São Paulo: Zoologia, no. 16, p. 281-287.

SILVANO, D., SCOTT, N., AQUINO, L., KWET, A. and BALDO, D.,2010. Rhinella icterica. In International Union for Conservation of Nature - IUCN. The IUCN Red List of Threatened Species. Version 2012.2. Cambridge. Available from: $<$ http://www.iucnredlist.org/ apps/redlist/details/54668/0>. Access in: 27 Jan. 2013.

SILVEIRA NETO, S., NAKANO, O., BARBIN, D. and NOVA, VAN.,1976. Manual de ecologia dos insetos. São Paulo: CERES.

TOLLEDO, J. and TOLEDO, LF., 2010. Tadpole of Rhinella jimi (Anura: Bufonidae) with comments on the tadpoles of species of the Rhinella marina group. Journal of Herpetology, vol. 44, no. 3, p. 480-483. http://dx.doi.org/10.1670/09-157.1.

VIEIRA, WLS. and ARZABE, C., 2008. Descrição do girino de Physalaemus cicada (Anura, Leiuperidae). Iheringia Série Zoologica, vol. 98, no. 2, p. 266-269.

ZUG, GR., VITT, LJ. and CALDWELL, JP.,2001. Herpetology: an introductory biology of amphibians and reptiles. 2nd ed. California: Academic Press. 